\title{
Establishment of a model of penicillin-resistant Streptococcus pneumoniae pneumonia in healthy CBA/J mice
}

\author{
K. TAKASHIMA, K. TATEDA, T. MATSUMOTO, T. ITO*, Y. IIZAWA $\dagger$, M. NAKAO $\dagger$ and K. YAMAGUCHI
}

Department of Microbiology, Toho University School of Medicine, Tokyo, * Drug Safety Research Laboratories and + Pharmaceutical Research Laboratories III, Takeda Chemical Industries Ltd, Osaka, Japan

\begin{abstract}
Examination of strain differences in the susceptibility of mice to experimental respiratory tract infection with penicillin-resistant Streptococcus pneumoniae TUM19 revealed that a fatal infection model could be induced in immunocompetent $\mathrm{CBA} / \mathrm{J}$ mice, but not in $\mathrm{C} 3 \mathrm{H} / \mathrm{HeN}, \mathrm{C} 57 \mathrm{BL} / 6$ or ICR mice. After intranasal instillation of $c$. $10^{6} \mathrm{cfu}$ of $S$. pneumoniae, the bacterial counts in the lungs of $\mathrm{CBA} / \mathrm{J}$ mice increased from $10^{5}$ to $10^{7} \mathrm{cfu}$ after 3-5 days, and gradually increased thereafter. The challenge organisms localised mainly in the lungs until 14 days after infection. Mice began to die c. 7 days after infection, and by 3 weeks most of the mice had died. Histopathologically, infiltration of neutrophils and lymphocytes around bronchi was observed from 1 day after infection, and fibrin deposition was seen in alveolar and bronchial spaces from 5 days. This model may be useful for investigating therapy of respiratory tract infection caused by penicillin-resistant $S$. pneumoniae because its pathological features resemble those observed in the human disease.
\end{abstract}

\section{Introduction}

Streptococcus pneumoniae is a common cause of community-acquired pneumonia [1,2]. Because this organism was originally highly susceptible to penicillin (MIC $<0.1 \mathrm{mg} / \mathrm{L})$, penicillin was the drug of choice for treatment. However, penicillin-resistant strains have been isolated with increasing frequency in virtually every part of the world in recent years [3], and successful treatment with penicillin is no longer guaranteed. In addition, penicillin-resistant strains may be resistant to a wide range of $\beta$-lactam and macrolide antibiotics $[4,5]$ and new strategies for treating these infections should be investigated.

A suitable infection model that closely resembles the features of human disease is necessary to investigate the optimal treatment of infections caused by penicillin-resistant strains. Azoulay-Dupuis et al. [6] and Moine et al. [7] described a murine model of

Received 5 Jan. 1996; revised version accepted 27 Feb. 1996.

Corresponding author: Dr K. Takashima. Present address: Pharmaceutical Research Laboratories III, Takeda Chemical Industries Ltd, 2-17-85 Jusohonmachi, Yodogawa-ku, Osaka 532, Japan. pneumonia caused by penicillin-resistant $S$. pneumoniae in leucopenic mice, but the strain was avirulent in immunocompetent mice. Their model represented acute infection, with a high incidence of bacteraemia in the early phase of infection, and most mice died within 2 days. However, $S$. pneumoniae frequently causes community-acquired pneumonia in healthy individuals and only $20-30 \%$ of pneumococcal pneumonia is accompanied by bacteraemia [8]. There have been no reports of experimental pneumonia caused by penicillin-resistant $S$. pneumoniae in healthy immunocompetent mice.

Strains of mice differ in susceptibility to pneumococcal infection [9] and these differences might be useful for establishing a new infection model with penicillinresistant $S$. pneumoniae. Therefore, the comparative susceptibility of various strains of mice to experimental respiratory tract infection with penicillinresistant $S$. pneumoniae strain TUM19 was examined.

\section{Materials and methods}

\section{Mice}

Five-to-seven-week-old female CBA/J, C57BL/6 and ICR mice were obtained from Charles River Japan Inc., Kanagawa, Japan. Six-to-seven-week-old female C3H/ 
HeN mice were obtained from SLC Japan Inc., Shizuoka, Japan. Mice were caged in groups of fiveto-ten and given food and water ad libitum.

\section{Organisms}

A clinical isolate of $S$. pneumoniae serotype 19 (strain TUM19), maintained as a stock culture in the Department of Microbiology, Toho University School of Medicine, Tokyo, Japan, was used. The MIC of benzylpenicillin (Meiji Seika Kaisha Ltd, Tokyo, Japan) against the organism, determined by the broth microdilution method according to the reference procedure recommended by the Japanese Society for Chemotherapy [10] was $2 \mathrm{mg} / \mathrm{L}$. The organisms were incubated at $37^{\circ} \mathrm{C}$ for $20 \mathrm{~h}$ on Mueller-Hinton Agar (MHA; Difco Laboratories) supplemented with defibrinated horse blood 5\% suspended in sterile physiological saline.

\section{Respiratory tract infection procedure}

Mice were anaesthetised by intraperitoneal injection of sodium pentobarbital (Nembutal; Abbott Laboratories, North Chicago, ILL, USA) $50 \mathrm{mg} / \mathrm{kg}$ of body weight and challenged intranasally by instillation of $40 \mu \mathrm{l}$ of bacterial suspension.

\section{Bacteriological examination}

Mice were killed by bleeding from the axillary artery and vein under ether anaesthesia. The lungs were removed aseptically and homogenised in $2 \mathrm{ml}$ of sterile physiological saline with a Teflon tissue homogeniser. The homogenates and blood were serially diluted 10fold with sterile physiological saline; $0.1 \mathrm{ml}$ of the various dilutions was inoculated on MHA plates supplemented with defibrinated horse blood $5 \%$ and incubated at $37^{\circ} \mathrm{C}$ for $20 \mathrm{~h}$. Colonies were counted and the results were expressed as the $\log _{10} \mathrm{cfu} / \mathrm{lung}$ and cfu/ml of blood.

\section{Histopathological examination}

The lungs of the mice were fixed in neutral buffered formalin $10 \%$ and embedded in paraffin. Sections were stained with haematoxylin and eosin, phosphotungstic acid haematoxylin solution, Gram's stain and azan stain, and examined by light microscopy.

\section{Results}

Susceptibility of various strains of mice to infection

After intranasal instillation of $2 \times 10^{7} \mathrm{cfu}$ of $S$. pneumoniae TUM19, eight of $11 \mathrm{CBA} / \mathrm{J}$ mice died within 7 days, whereas the all other strains of mice $(\mathrm{C} 3 \mathrm{H} / \mathrm{HeN}, \mathrm{C} 57 \mathrm{BL} / 6$ and ICR) survived (Table 1). Most of the mice that survived had no gross pulmonary lesions and eliminated the organisms from their lungs. Therefore, CBA/J mice were chosen for the following experiments.

\section{Effect of challenge dose}

With challenge doses of $5.6 \times 10^{6}$ and $1.1 \times 10^{6} \mathrm{cfu} /$ mouse, most mice died c. 7 days and 11 days after infection, respectively (data not shown). With a challenge dose of $2.2 \times 10^{5} \mathrm{cfu} /$ mouse, all five mice survived for 14 days after infection; bacteria were not recovered from the lungs of two of these mice. Thus, $\geqslant 10^{6} \mathrm{cfu} /$ mouse were required to cause uniform infection.

\section{Bacteriological examination}

After challenge with c. $10^{6} \mathrm{cfu} /$ mouse, the bacterial counts in the lungs increased slowly from $10^{4}$ to

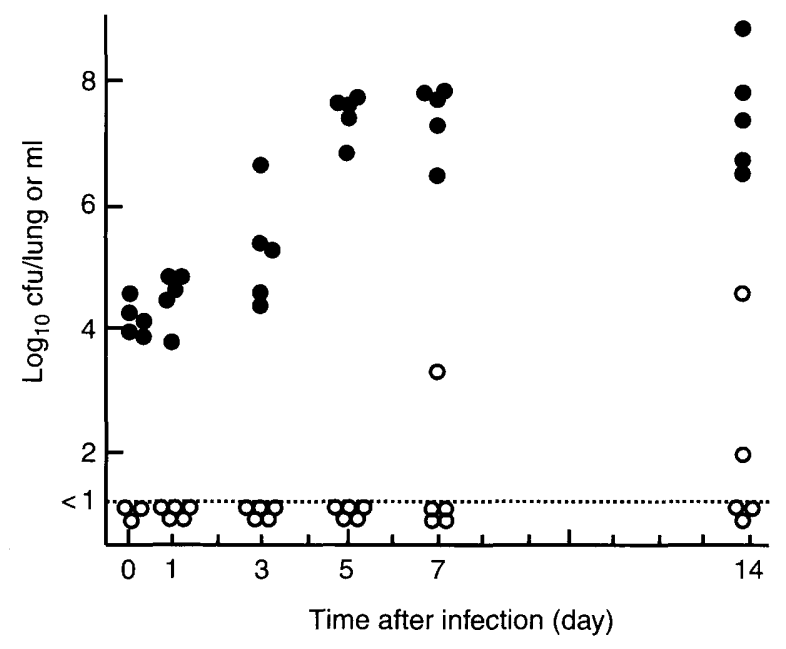

Fig. 1. Bacterial counts in the lungs $(O)$ and blood $(O)$ of $\mathrm{CBA} / \mathrm{J}$ mice infected with $S$. pneumoniae TUM19 by intranasal instillation. Each point represents the value for a mouse.

Table 1. Susceptibility of various strains of mice to intranasal instillation with S. pneumoniae TUM19*

\begin{tabular}{lccc}
\hline $\begin{array}{l}\text { Mouse } \\
\text { strain }\end{array}$ & $\begin{array}{c}\text { Mortality } \\
\text { at } 7 \text { days } \\
\text { (death/total) }\end{array}$ & $\begin{array}{c}\text { Gross pulmonary } \\
\text { lesion } \\
\text { (positive/total) }\end{array}$ & $\begin{array}{c}\text { Bacterial recovery } \\
\text { from lung } \\
\text { (positive/total) }\end{array}$ \\
\hline $\mathrm{CBA} / \mathrm{J}$ & $8 / 11$ & $\mathrm{NT}$ & $\mathrm{NT}$ \\
$\mathrm{C} 3 \mathrm{H} / \mathrm{HeN}$ & $0 / 11$ & $3 / 11$ & $1 / 11$ \\
$\mathrm{C} 57 \mathrm{BL} / 6$ & $0 / 5$ & $0 / 5$ & $0 / 5$ \\
$\mathrm{ICR}$ & $0 / 5$ & $0 / 5$ & $0 / 5$ \\
\hline
\end{tabular}

NT, not tested.

${ }^{*}$ c. $2 \times 10^{7} \mathrm{cfu} /$ mouse. 
$10^{5} \mathrm{cfu} /$ lung by 3 days after infection and increased rapidly to $10^{7} \mathrm{cfu}$ at 5 days. The number of bacteria in the lungs increased gradually thereafter (Fig. 1). Some mice developed bacteraemia when the bacterial counts in the lungs reached $>10^{8} \mathrm{cfu}$ from 7 days after infection. Mice began to die c. 7 days after infection, and by 3 weeks $83 \%$ (48 of 58) had died.

\section{Histopathological changes}

Histopathological examination of lung from infected mice revealed the existence of bronchopneumonia. Infiltration of neutrophils and lymphocytes around bronchi and hyperplasia of alveolar epithelia were observed at 1 day (Fig. 2A); haemorrhage and necrosis of alveolar epithelia were seen from 3 days after
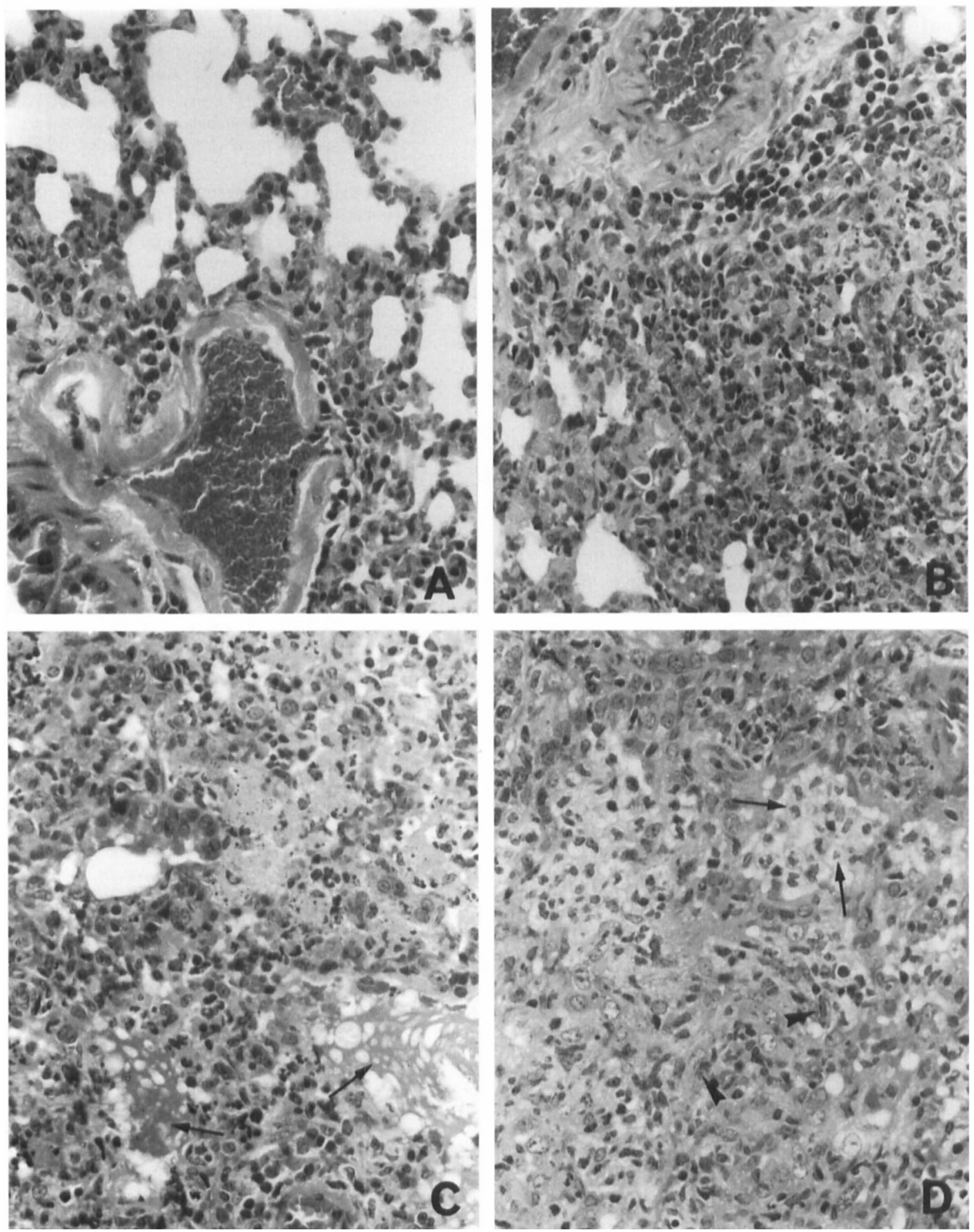

Fig. 2. Histopathological changes in the lungs of CBA/J mice infected with $S$. pneumoniae TUM 19 by intranasal instillation. Stained with haematoxylin and eosin. A, Neutrophil and lymphocyte infiltration around bronchi and hyperplasia of alveolar epithelia 1 day after infection $(\times 400)$. B, Haemorrhage and necrosis of alveolar epithelia 3 days after infection $(\times 400)$. C, Fibrin deposition (arrow) in the bronchial and alveolar spaces 5 days after infection $(\times 400)$. D, Proliferation of fibroblasts (arrow head) and infiltration of foam cells (arrow) 14 days after infection $(\times 400)$. 
infection (Fig. 2B). Similar lesions extended throughout the lungs thereafter (Fig. 2C, D). In addition to these inflammatory responses, fibrin deposition in the bronchial and alveolar spaces was found at 5 days (Fig. 2C), and fibrosis accompanied by proliferation of fibroblasts and infiltration of foam cells was observed at 14 days (Fig. 2D). Fibrin and collagen fibres were clearly identified by phosphotungstic acid, haematoxylin stain and azan stain, respectively. The infecting organisms in the bronchial and alveolar spaces were detected by Gram's stain after 5 days of infection (data not shown).

\section{Discussion}

It has been thought difficult to establish an experimental respiratory tract infection model with penicillinresistant $S$. pneumoniae in immunocompetent mice. Clinical isolates of penicillin-resistant $S$. pneumoniae predominantly belong to serotypes $6,14,19$ and 23 $[3,4]$, which are naturally avirulent for mice [11]. Several investigators have failed to induce pneumonia with any penicillin-resistant strains belonging to these serotypes in immunocompetent C57BL/6 and Swiss mice $[6,7]$. This study also failed to induce pneumonia in $\mathrm{C} 3 \mathrm{H} / \mathrm{HeN}, \mathrm{C} 57 \mathrm{BL} / 6$, and ICR mice by intranasal challenge with serotype 19 strain (TUM19). However, $\mathrm{CBA} / \mathrm{J}$ mice showed high susceptibility to the infection: most mice died after intranasal challenge with $\geqslant 10^{6} \mathrm{cfu}$ of the organism. Genetic defects in the host defences against bacterial infection have not been reported in $\mathrm{CBA} / \mathbf{J}$ mice and it is unclear why they are susceptible to pneumococcal infection.

Intranasal inoculation of CBA/J mice with $10^{6} \mathrm{cfu}$ of $S$. pneumoniae TUM19 induced a fatal infection. The challenge organisms localised mainly in the lungs without causing bacteraemia, at least in the first week of infection, while the bacterial counts in the lungs increased from $10^{4}$ to $10^{7} \mathrm{cfu}$. Histopathological features such as intense infiltration of inflammatory cells and fibrin deposition in alveolar spaces resembled the features of pneumococcal pneumonia in man [12].
As the course of the infection is long and lung lesions develop gradually, this model might be useful for examining the effect of antibiotics at the various stages of pneumonia caused by penicillin-resistant $S$. pneumoniae. Furthermore, it is also possible to investigate methods for the suppression of inflammation induced by pneumococcal infection.

\section{References}

1. Woodhead MA, Macfarlane JT, McCracken JS, Rose DH, Finch RG. Prospective study of the aetiology and outcome of pneumonia in the community. Lancet 1987; 1: 671-674.

2. Pachon J, Prados MD, Capote F, Cuello JA, Garnacho J, Verano A. Severe community-acquired pneumonia. Etiology, prognosis, and treatment. Am Rev Respir Dis 1990; 142: 369373.

3. Appelbaum PC. Antimicrobial resistance in Streptococcus pneumoniae: an overview. Clin Infect Dis 1992; 15: 77-83.

4. Baquero F, Martínez-Beltrán J, Loza E. A review of antibiotic resistance patterns of Streptococcus pneumoniae in Europe. $J$ Antimicrob Chemother 1991; 28 Suppl C: 31-38.

5. Liñares J, Alonso T, Pérez JL et al. Decreased susceptibility of penicillin-resistant pneumococci to twenty-four $\beta$-lactam antibiotics. $J$ Antimicrob Chemother 1992; 30: 279-288.

6. Azoulay-Dupuis E, Vallée E, Veber B, Bédos JP, Bauchet J, Pocidalo J-J. In vivo efficacy of a new fluoroquinolone, sparfloxacin, against penicillin-susceptible and -resistant and multiresistant strains of Streptococcus pneumoniae in a mouse model of pneumonia. Antimicrob Agents Chemother 1992; 36: 2698-2703.

7. Moine $\mathrm{P}$, Vallée E, Azoulay-Dupuis E et al. In vivo efficacy of a broad-spectrum cephalosporin, ceftriaxone, against penicillinsusceptible and -resistant strains of Streptococcus pneumoniae in a mouse pneumonia model. Antimicrob Agents Chemother 1994; 38: 1953-1958.

8. Boulnois GJ. Pneumococcal proteins and the pathogenesis of disease caused by Streptococcus pneumoniae. J Gen Microbiol 1992; 138: 249-259.

9. Briles DE, Horowitz J, McDaniel LS et al. Genetic control of the susceptibility to pneumococcal infection. Curr Top Microbiol Immunol 1986; 124: 103-120.

10. Japanese Society for Chemotherapy. Determination of minimum inhibitory concentration (MIC) by the micro-dilution method. Chemotherapy 1990; 38: 102-105.

11. Briles DE, Crain MJ, Gray BM, Forman C, Yother J. Strong association between capsular type and virulence for mice among human isolates of Streptococcus pneumoniae. Infect Immun 1992; 60: 111-116.

12. Johnston RB. Pathogenesis of pneumococcal pneumonia. Rev Infect Dis 1991; 13 Suppl 6: S509-S517. 